\title{
Direct and Efficient Plant Regeneration from Different Explants Sources of Potato Cultivars as Influenced by Plant Growth Regulators
}

\author{
Shambhu P. Dhital ${ }^{1}$, Hak T. Lim ${ }^{2}$ and Hira K. Manandhar' \\ ${ }^{1}$ Nepal Agricultural Research Council (NARC), Khumaltar, Lalitpur \\ ${ }^{2}$ Department of Plant Biotechnology, the Center for the Korea Potato Genetic Resources \\ (KPGR), Kangwon National University, Chuncheon, Kangwon, Republic of Korea \\ e-mail: spdhital59@yahoo.com
}

\begin{abstract}
Response of widely grown potato cv. Superior and newly developed cvs. Gui valley and Bora valley to plant growth regulators (PGRs) for direct plant regeneration from internode, leaf blade and petiole explants were investigated. The explants were cultured on a MS solid medium supplemented with different concentrations and combinations of 6-benzylaminopurine (BAP), 1-naphthaleneacetic acid (NAA), zeatin, indole-3-acetic acid (IAA) and gibberellic acid $\left(\mathrm{GA}_{3}\right)$. Potato cv. Superior, regenerated direct shoot without callus and root formation on MS solid medium supplemented with BAP or zeatin, proliferous roots were produced on NAA or IAA supplemented medium and only some calli were produced on $\mathrm{GA}_{3}$ supplemented medium. The regeneration response varied with different concentrations of PGRs, singly and also in combinations. In the case of combined application of PGRs, the highest shoot regeneration (75.3\%) and number of shoot per explant (11.5) and number of roots per explant (7.0) were obtained from the MS solid medium supplemented with zeatin $\left(2 \mathrm{mg} \mathrm{l}^{-1}\right)$, NAA $\left(0.1 \mathrm{mg} \mathrm{l}^{-1}\right)$ and GA $\left.0.1 \mathrm{mg} \mathrm{l}^{-1}\right)$. Among the three types of explants evaluated, internodes produced the highest number of shoots and roots for both potato cvs. Gui valley and Bora valley, and petiole produced the least number of shoots and roots. The regenerated shoots were rooted in PGRs-free MS solid medium and successfully established under glasshouse condition. Leaf, flower, and tuber morphology were identical to in vitro control and mother plants in the same conditions. This optimized regeneration system can be used for rapid shoot proliferation and also for gene transformation.
\end{abstract}

Key words: Bora valley, Gui valley, internode, leaf, petiole, PGRs, regeneration

\section{Introduction}

Potato (Solanum tuberosum L.) is mainly propagated by means of vegetative propagation, which is subjected to many biotic and abiotic stresses. In vitro culture of axillary buds is commonly used in the production of disease-free plantlets for germplasm exchange, conservation, and seed tuber production. It is also an important candidate for in vitro genetic manipulation for the development of desirable variety (Synder \& Belknap 1993). Due to this reason, various regeneration (Hulme et al. 1992) and transformation studies have been made toward its improvement (Imai et al. 1993). It has therefore become desirable to develop more effective in vitro regeneration system for this crop. Plants regenerated through direct organogenesis are considered as true to type and don not exhibit somaclonal variation. Organogenesis is highly dependent on the interaction between naturally occurring endogenous growth hormones and exogenous growth regulators added to the culture medium (Smith et al. 2006, Yadav \& Sticklen 1995). 
Development of efficient regeneration system is also necessary for the transformation of desirable genes from one plant species to other plant species. Plant tissue culture and development of regeneration system is influenced by several factors such as species variability, kinds of tissue, nutritional components of the medium, plant growth regulators and culture conditions. Transformation frequencies, however, are often low, being dependent upon the nature of the genotype and the efficiency of in vitro regeneration of these genotypes (Smith et al. 2006).

Among the potato genotypes used in the present study, Superior is an American cv. and popular in Korea since 1960s, and other two cvs. Gui valley and Bora valley are recently developed in Korea. Gui valley is high yielding, excellent for chips and French fries (Lim et al. 2009), and Bora valley is also high yielding, high in antioxidant and phenolic compound (Lim et al. 2008). To date, there have been no studies on direct shoot regeneration of Gui valley and Bora valley. The objective of this work was to study the response of new potato cultivars for direct and efficient regeneration using different explants and PGRs.

\section{Methodology}

In vitro multiplication and explant preparation In vitro plantlets of potato cvs. Superior, Gui valley and Bora valle were obtained from the Center for Korea Potato Genetic Resources (KPGR), Kangwon National University, Korea and sub-cultured on a MS (Murashige \& Skoog 1962) solid medium containing $3 \%$ sucrose for four weeks at $25 \pm 2{ }^{\circ} \mathrm{C}$ under 2000 lux fluroscent light for $16 \mathrm{~h}$. Internode, leaf blade and petiole of four-week old plantlets were used as explants. Axillary buds were removed from explants and the remainder portion was cut into 4-5 strips aseptically. These explants were cultured in various test culture media containing filter-sterilized plant growth regulators (PGRs) as treatments. Ten explants were planted in each Petri-dish (90 mm in diameter) and a minimum of three Petri-dishes were assigned to each treatment.

\section{Regeneration}

\section{Experiment 1. Effect of different PGRs for direct regeneration}

The experiment was designed to investigate the effect of PGRs at different levels on direct regeneration by using internode segment of in vitro explants of potato cv. Superior. Twenty explants were transferred into the MS solid medium containing 3\% sucrose, and three levels $\left(0.1,1.0\right.$ and $2.0 \mathrm{mg} \mathrm{l}^{-1}$ ) each of 6benzylaminopurine (BAP), 1-naphthaleneacetic acid (NAA), zeatin, indole-3-acetic acid (IAA) and gibberellic acid $\left(\mathrm{GA}_{3}\right)$.

\section{Experiment 2. Combined application of PGRs for direct regeneration}

The experiment was conducted to determine the effect of combined application of different PGRs on direct regeneration of explants of potato cv. Gui valley. Combinations of previously determined effective concentration of PGRs (based on Experiment 1) were evaluated for their ability to enhance regeneration of explants. MS solid medium containing $3 \%$ sucrose was used as basal medium. The treatment combinations were: (i) BAP $\left(2 \mathrm{mg} \mathrm{l}^{-1}\right)$ plus $\mathrm{GA}_{3}\left(1 \mathrm{mg} \mathrm{l}^{-1}\right)$, (ii) BAP (2 $\mathrm{mg} \mathrm{l}^{-1}$ ) plus NAA $\left(0.1 \mathrm{mg} \mathrm{l}^{-1}\right)$, (iii) BAP $\left(2 \mathrm{mg} \mathrm{l}^{-1}\right)$ plus IAA (0.1 $\left.\mathrm{mg} \mathrm{l}^{-1}\right)$, (iv) zeatin $\left(2 \mathrm{mg} \mathrm{l}^{-1}\right)$ plus NAA $(0.1 \mathrm{mg}$ $\left.\mathrm{l}^{-1}\right)$, (v) zeatin $\left(2 \mathrm{mg} \mathrm{l}^{-1}\right)$ plus NAA $\left(0.1 \mathrm{mg} \mathrm{l}^{-1}\right)$ plus $\mathrm{GA}_{3}$ $\left(0.1 \mathrm{mg} \mathrm{l}^{-1}\right)$, and (vi) without PGRs as a control.

\section{Experiment 3. Direct regeneration from different types of explants}

The experiment was conducted to evaluate types of explants (internode, petiole and leaf) of potato cvs. Gui valley and Bora valley and for direct regeneration. The most effective two combinations of PGRs (based on Experiment 2): (i) BAP (2 $\left.\mathrm{mg} \mathrm{l}^{-1}\right)$ plus $\mathrm{GA}_{3}\left(0.1 \mathrm{mg} \mathrm{l}^{-}\right.$ $\left.{ }^{1}\right)$ and (ii) zeatin $\left(2 \mathrm{mg} \mathrm{l}^{-1}\right)$ plus NAA $\left(0.1 \mathrm{mg} \mathrm{l}^{-1}\right)$ plus $\mathrm{GA}_{3}\left(0.1 \mathrm{mg} \mathrm{l}^{-1}\right)$ were used in this study.

\section{In vitro regeneration and glasshouse establishment}

Six-week old 2-3 cm long plantlets from internode were transferred to the PGR-free MS solid medium containing $3 \%$ sucrose and incubated for another six weeks at $25 \pm 2{ }^{\circ} \mathrm{C}$ under $16 \mathrm{~h}$ photoperiod to obtain plantlets. Ten explants were sub-cultured in each glass jar (400 ml). The regenerated plantlets and in vitro plantlets (as control) were used as planting materials for further studies. For acclimatization, rooted and shooted plantlets of potato cvs. Gui valley and Bora valley were transferred to polyvinyl pots containing soil and grown under plastic house conditions for three months. Plants regenerated from explants were compared with those developed from single nodal cuttings for leaf and tuber morphology. 


\section{Results and Discussion}

The highest frequency of shoot induction (40\%) was observed on the MS solid medium supplemented with $2 \mathrm{mg} \mathrm{l}^{-1}$ BAP or $2 \mathrm{mg} \mathrm{l}^{-1}$ zeatin, and the highest (3) number of shoot per explant was obtained with $2 \mathrm{mg} \mathrm{l}^{-}$ ${ }^{1}$ zeatin. Induction of shoot was higher with the higher concentration ( $>1 \mathrm{mg} \mathrm{l}^{-1}$ ) of BAP and zeatin. Adventitious buds developed directly from cut surface, which initially resembled knob-like structure and later developed into new plant (Fig. 1). None of the explants cultured in the BAP, zeatin and $\mathrm{GA}_{3}$ supplemented MS solid medium produced roots. The explants cultured in the MS solid medium supplemented with IAA or $\mathrm{GA}_{3}$ did not produce shoots. However, root formation was found in NAA and IAA supplemented MS solid medium (Table 1).

Table 1. Effect of single PGR application on callus induction, shoot regeneration and root formation from internodal explants of potato cv. Superior

\begin{tabular}{|c|c|c|c|c|c|c|c|}
\hline \multicolumn{2}{|c|}{ PGR (mg l $\left.{ }^{-1}\right)$} & $\begin{array}{c}\text { Explant } \\
\text { used (No.) }\end{array}$ & Nature of callus & $\begin{array}{c}\text { Callus } \\
\text { induction } \\
(\%)\end{array}$ & $\begin{array}{c}\text { Shoot } \\
\text { induction } \\
(\%)\end{array}$ & $\begin{array}{c}\text { Shoot/explant } \\
\text { (No.) }\end{array}$ & $\begin{array}{c}\text { Root/explan } \\
\text { t (No.) }\end{array}$ \\
\hline \multirow[t]{3}{*}{ BAP } & 0.1 & 20 & Compact, green & $10.0 \pm 1.18$ & $30.0 \pm 5.29$ & $1.5 \pm 0.30$ & 0.0 \\
\hline & 1.0 & 20 & Compact, green & 0.0 & $35.5 \pm 4.96$ & $1.0 \pm 0.32$ & 0.0 \\
\hline & 2.0 & 20 & Compact, green & $15.2 \pm 1.43$ & $40.5 \pm 5.31$ & $2.0 \pm 0.64$ & 0.0 \\
\hline \multirow[t]{3}{*}{ Zeatin } & 0.1 & 20 & Compact, green & $10.1 \pm 1.06$ & $20.3 \pm 3.05$ & $1.5 \pm 0.57$ & 0.0 \\
\hline & 1.0 & 20 & Compact, green & $20.4 \pm 2.52$ & $30.2 \pm 6.19$ & $2.5 \pm 0.46$ & 0.0 \\
\hline & 2.0 & 20 & Compact, green & $10.1 \pm 1.66$ & $40.0 \pm 6.87$ & $3.0 \pm 0.72$ & 0.0 \\
\hline \multirow[t]{3}{*}{ NAA } & 0.1 & 20 & Friable, yellowish green & $80.3 \pm 7.45$ & 0.0 & 0.0 & $7.5 \pm 0.75$ \\
\hline & 1.0 & 20 & Friable, yellowish green & $99.0 \pm 1.02$ & $5.1 \pm 1.40$ & $1.0 \pm 0.29$ & $9.5 \pm 1.40$ \\
\hline & 2.0 & 20 & Friable, yellowish green & $98.8 \pm 1.27$ & 0.0 & 0.0 & $9.0 \pm 1.04$ \\
\hline \multirow[t]{3}{*}{ IAA } & 0.1 & 20 & Nodular, compact, light green & $71.0 \pm 5.03$ & $5.5 \pm 1.08$ & $0.5 \pm 0.17$ & $5.5 \pm 0.95$ \\
\hline & 1.0 & 20 & Nodular, compact, light green & $60.2 \pm 7.59$ & $8.6 \pm 1.43$ & $1.0 \pm 00.35$ & $4.0 \pm 0.96$ \\
\hline & 2.0 & 20 & Nodular, compact, light green & $81.0 \pm 4.72$ & 0.0 & 0.0 & $5.0 \pm 0.85$ \\
\hline \multirow[t]{3}{*}{$\mathrm{GA}_{3}$} & 0.1 & 20 & Nodular, compact, light green & $10.1 \pm 1.54$ & 0.0 & 0.0 & 0.0 \\
\hline & 1.0 & 20 & Nodular, compact, light green & $10.2 \pm 1.47$ & 0.0 & 0.0 & 0.0 \\
\hline & 2.0 & 20 & Nodular, compact, light green & $10.1 \pm 1.03$ & 0.0 & 0.0 & 0.0 \\
\hline Control & - & 20 & Not detected & 0.0 & 0.0 & 0.0 & 0.0 \\
\hline
\end{tabular}

Data are presented as mean \pm standard error.

In the case of combined application of PGRs, MS solid medium supplemented with zeatin $\left(2 \mathrm{mg} \mathrm{l}^{-1}\right)$, NAA (0.1 $\left.\mathrm{mg} \mathrm{l}^{-1}\right)$ and $\mathrm{GA}_{3}\left(0.1 \mathrm{mg} \mathrm{l}^{-1}\right)$ gave the highest frequency of shoot regeneration (induction) (75.3\%) and the highest number of shoot per explant (11.5) and the higher number of root per plant (7.0), followed by the medium supplemented with BAP $\left(2 \mathrm{mg} \mathrm{l}^{-1}\right)$ and $\mathrm{GA}_{3}(1$ $\mathrm{mg} \mathrm{l}^{-1}$ ) (Table 2). The present study showed that the appropriate concentrations of combination of auxin, gibberellins and cytokinin are essential for the direct and efficient regeneration of explants without callus formation. The presence of a cytokinin in the medium is essential for adventitious shoot formation (Makunga et al. 2005). The rate of regeneration was low on MS solid medium supplemented with single PGR whereas the regeneration rate was high on the MS solid medium supplemented with NAA in combination with BAP, zeatin and $\mathrm{GA}_{3}$ (Table 2). Combined use of BAP, $\mathrm{GA}_{3}$ and NAA in the MS solid medium gave higher regeneration rate without callus formation in potato cv. Taedong valley (Fang et al. 2007). In the present study, the regeneration rate was higher by two times and shoots per explant was higher by three times in combined application of PGRs than the single application. 
The shoot regeneration frequency and the number of shoot per explant varied with leaf, petiole and internode explants (Table 3). Internode explants showed higher frequency of shoot regeneration and number of shoots per explants than the leaf and petiole explants. This could be attributed to mature and more vascular tissue in the internodes. The frequency of callus induction was higher from leaf explant than from the internode and petiole explants. In some other studies, the frequency of callus induction from leaf explants was higher than from petiole and internodal explants of Codonopss lanceolata (Ghimire 2008) and strawberry (Passey et al. 2003).

Table 3. Effect of combined application of selected PGRs on shoot regeneration and root formation from internodal, petiole and leaf blade explants of potato cvs. Gui valley and Bora valley

\begin{tabular}{|c|c|c|c|c|c|c|}
\hline \multirow[t]{2}{*}{ Cultivar } & \multirow{2}{*}{$\begin{array}{l}\text { Type of } \\
\text { explant }\end{array}$} & \multirow{2}{*}{$\begin{array}{l}\text { Explant } \\
\text { used (No.) }\end{array}$} & \multicolumn{2}{|c|}{ BAP and $\mathrm{GA}_{3} \dagger$} & \multicolumn{2}{|c|}{ Zeatin, NAA and $\mathrm{GA}_{3} \ddagger$} \\
\hline & & & $\begin{array}{c}\text { Shoot/explant } \\
\text { (No.) }\end{array}$ & $\begin{array}{c}\text { Root/explant } \\
\text { (No.) }\end{array}$ & $\begin{array}{c}\text { Shoot/explant } \\
\text { (No.) }\end{array}$ & Root/explant (No.) \\
\hline \multirow[t]{3}{*}{ Gui valley } & Internodes & 30 & $9.0 \pm 1.12$ & $4.8 \pm 0.71$ & $10.0 \pm 1.59$ & $5.0 \pm 0.85$ \\
\hline & Petiole & 30 & $2.2 \pm 0.68$ & 0.0 & $2.2 \pm 0.71$ & $2.2 \pm 0.72$ \\
\hline & Leaf & 30 & $3.0 \pm 1.01$ & $2.0 \pm 0.60$ & $5.0 \pm 1.04$ & $2.0 \pm 0.60$ \\
\hline \multirow[t]{3}{*}{ Bora valley } & Internodes & 30 & $15.0 \pm 1.85$ & $10.5 \pm 1.77$ & $10.5 \pm 1.78$ & $4.9 \pm 1.11$ \\
\hline & Petiole & 30 & $1.0 \pm 0.52$ & $3.0 \pm 1.04$ & 0.0 & $1.0 \pm 0.61$ \\
\hline & Leaf & 30 & $3.0 \pm 0.95$ & $2.0 \pm 0.60$ & $3.0 \pm 1.04$ & $2.2 \pm 0.71$ \\
\hline
\end{tabular}

Data are presented as mean \pm standard error.

$\dagger=\operatorname{BAP}\left(2 \mathrm{mg} \mathrm{l}^{-1}\right)$ and $\mathrm{GA}_{3}\left(1 \mathrm{mg} \mathrm{l}^{-1}\right)$.

$\ddagger=$ Zeatin $\left(2 \mathrm{mg} \mathrm{l}^{-1}\right)$, NAA $\left(0.1 \mathrm{mg} \mathrm{l}^{-1}\right)$ and $\mathrm{GA}_{3}\left(0.1 \mathrm{mg} \mathrm{l}^{-1}\right)$.

Majority of calli as well as buds were induced from the cut edges of the explants. The cut edges provided a way for nutrients and growth regulator to be absorbed efficiently from the medium (Sarwar \& Skirvin 1997). In the case of internodal explants, frequency of shoot regeneration was higher at both ends of explants than at the cut portions in between. An increased intensity of vascular tissue and level of phytohormone and metabolites at the end portions of the explants might be responsible for the increase in shoot regeneration (Karam \& Majathoud 2000). The frequency of direct shoot organogenesis varied among the types of explants (leaf, petiole and internode). Such direct regeneration system is useful to produce a rapid multiplication of valuable germplasm in a short period without any genetic changes. The morphology of the regenerated plantlets was similar to the mother plants and that must be due to the fact that shoots were regenerated directly from the explants (Fig. 1).

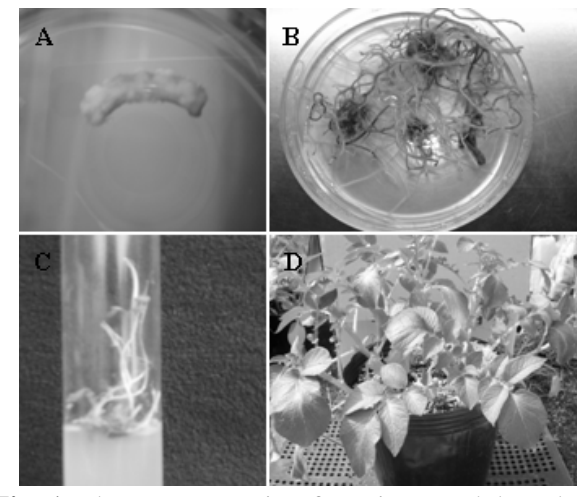

Fig. 1. Plant regeneration from internodal explants in potato cv. Gui valley under in vitro and in vivo conditions.

A. Internodal explants cultured in MS solid medium supplemented with Zeatin (2 $\left.\mathrm{mg} \mathrm{l}^{-1}\right)$, NAA (0.1 $\left.\mathrm{mg} \mathrm{l}^{-1}\right)$ and $\mathrm{GA}_{3}\left(0.1 \mathrm{mg} \mathrm{l}^{-1}\right)$ after two weeks of culture.

B. Regenerated internodal explants in MS solid medium supplemented with Zeatin ( $\left.2 \mathrm{mg} \mathrm{l}^{-1}\right)$, NAA $(0.1 \mathrm{mg}$ $\left.\mathrm{l}^{-1}\right)$ and $\mathrm{GA}_{3}\left(0.1 \mathrm{mg} \mathrm{l}^{-1}\right)$ after six weeks of culture.

C. Shoot and root developed plantlets after regenerated in MS solid medium.

D. Regenerated plant grown in sterilized commercial soil under glasshouse conditions after six weeks of plantation. 
In conclusion, these studies demonstrated that combinations of zeatin, NAA and $\mathrm{GA}_{3}$ as well as BAP and $\mathrm{GA}_{3}$ could be used in potato cvs. Gui valley and Bora valley for direct and efficient regeneration under in vitro conditions. For efficient regeneration, internodal explants were found more appropriate than the petiole and leaf blade explants. These results will be useful for gene transformation and rapid shoot proliferation work in potatoes.

\section{Acknowledgements}

The work was supported by a grant to Prof. Hak Tae Lim at the Potato Valley Co., Ltd. and Center for the Korea Potato Genetic Resources (KPGR), Kangwon National University from the Agricultural R\&D Promotion Center, Ministry for Food, Agriculture, Forestry and Fisheries, Republic of Korea.

\section{References}

Fang, Y.L., J.S. Kim, S. Gong, H.S. Mo, S.K. Min, S.K. Kwon, K.H. Li and H.T. Lim. 2007. Development of antibiotic marker free potato having resistance against two herbicides. Korean Journal of Plant Biotechnology 43(3):253-261.

Ghimire, B.K. 2008. Agrobacterium-mediated y-TMT gene transformation, expression and characterization in Codonopsis lanceolata (Siebold and Zucc.) trautv. Ph.D. Thesis. Department of Applied Plant Science, Graduate School, Kangwon National University, Republic of Korea 168 pp.

Hulme, J.S, E.S. Higgins and R. Shield. 1992. An efficient genotype-independent method for regeneration of potato plants from leaf tissue. Plant Cell Tissue and Organ Culture 31:161-167.

Imai, T, R. Aida and T. Ishige. 1993. High frequency of tetraploidy In: Agrobacterium-mediated transformants regenerated from tuber discs of diploid potato lines. Plant Cell Reports 12:299-302.

Karam, N.S. and M. Al-Majathoud. 2000. Direct shoot regeneration and microtuberization in wild Cyclamen persicum Mill. using seedling tissue. Horticulture Science 86:235-302.
Lim, H.T., S.P. Dhital, D.M. Khu, K.H. Li, S.P. Choi, C.W. Kang, T.J. Kim, H.S. Mo, W.N. Hwang, W.J. Lee and H.S. Kim. 2009. 'Gui valley’: A high yielding potential and good processing potato cultivar. Korean Journal of Plant Resources 22(6):483-488.

Lim, H.T., W.N. Hwang, W.J. Lee and S.P. Dhital. 2008. Breeding potato varieties for all year round production with earliness: achievements and prospects with reference to Korea. In: Global Potato Conference 2008 (Eds. J. Gopal, D. Pattanayak, D. Kumar, P.M. Govindakrishnan, and B. Singh). New Delhi, India.

Makunga, N.P., A.K. Jager and J.V. Staden. 2005. An improved system for the in vitro regeneration of Thapsia garganica via direct organogenesis influence of auxins and cytokinins. Plant Cell Tissue and Organ Culture 82:271-280.

Murashige, T. and F. Skoog. 1962. A revised medium for rapid growth and bioassays with tobacco tissue cultures. Physiology of Plant 15:473-479

Passey, A.J., K.J. Barrett and D.J. James. 2003. Adventitious shoot regeneration from some commercial strawberry cultivars (Fragaria ananassa Duch.) using a range of explant types. Plant Cell Reports 21:397-401.

Sarwar, M. and R.M. Skirvin. 1997. Effect of thidiazuron and benzylaminopurine on adventitious shoot regeneration from leaves of the strains of Macintosh apple (Malus domestica Borkh.) in vitro. Horticulture Science 68:95-100.

Smith, G.R., L. Prakash, R.J. Geijskes, W. Lifang, E. Adrian, P. Christopher and N. Berding. 2006. Developmental and hormonal regulation of direct shoot organogesis and somatic embryogenesis in sugarcane (Saccharum spp. Interspecific hybrids) leaf culture. Plant Cell Reports 25:10071015.

Synder, G. W. and W.R. BeIknap. 1993. A modified metl1od for routine Agroba.cterium-mediated transformation of in vitro grown potato microtubers. Plant Cell Reports 12:324- 327.

Yadav, N.R. and M.B. Sticklen. 1995. Direct and efficient plant regeneration from leaf explants of Solanum tuberosum L. cv. Bintje. Plant Cell Reports 14:645-647. 
Nepal Journal of Science and Technology 12 (2011) 1-6 